\title{
A QUEDA DO MURO DE BERLIM: UM ESTUDO COM FONTES BRASILEIRAS ${ }^{1}$
}

\author{
Carlos Federico Domínguez Avila
}

\begin{abstract}
RESUMO
O artigo explora os acontecimentos que resultaram na queda do muro de Berlim, bem como algumas das suas mais importantes conseqüencias, inclusive no que diz respeito à reunificação alemã, em 1990. O texto utiliza prioritariamente fontes primárias resgatadas no Arquivo Histórico do Ministério das Relações Exteriores do Brasil - após vários anos de resguardo legal. Também são utilizadas fontes secundárias - isto é, literatura especializada na temática publicada no Brasil e no exterior. Analiticamente o artigo constata a transcendental relevância da queda do muro de Berlim e eventos subseqüentes, tanto na própria Alemanha, quanto na Europa e no mundo. Nessa linha, o texto alude ao colapso político e econômico da República Democrática da Alemanha (RDA), aos atores fundamentais que levaram ao esboroamento do muro, aos condicionantes domésticos, inter-alemães, europeus e globais que incidiram no processo de reunificação da nação alemã e aos dilemas específicos da cidade de Berlim no contexto geral da reunificação germânica. O trabalho inclui uma pós-data de novembro de 2009, em que se comenta brevemente as comemorações do vigésimo aniversário da queda do muro de Berlim.
\end{abstract}

PALAVRAS-CHAVE: República Democrática da Alemanha; Berlim; Guerra Fria; reunificação alemã; República Federal da Alemanha.

\section{INTRODUÇÃO}

Desde sua construção, em agosto de 1961, o muro de Berlim sempre foi identificado com o governo do Partido Socialista Unificado da Alemanha (SED, na sigla em alemão) e especificamente com Walter Ulbricht e Erich Honecker. O máximo símbolo da divisão da cidade de Berlim, da Alemanha, do continente europeu e, em certo sentido, do conflito da Guerra Fria era justificado pelos dirigentes comunistas germano-orientais sob o argumento de proteger a economia da República Democrática da Alemanha (RDA) do saqueio, do contrabando e da especulação - além de controlar a população e evitar a fuga em massa de trabalhadores qualificados para o setor oeste da cidade, território da República Federal da Alemanha (RFA). Em 1971, Erich Honecker assumiu o cargo de primeiro secretário do SED, tornandose, de fato, o chefe de Estado da RDA até sua

\footnotetext{
1 O autor do artigo agradece os comentários dos doutores Amado Luiz Cervo e Lídia de Oliveira Xavier. Igualmente, agradecem-se as observações e recomendações dos dois pareceristas anônimos da Revista de Sociologia e Política que avaliaram o texto ora publicado.
}

"renúncia", em 17 de outubro de 1989 (MONIZ BANDEIRA, 2001) $)^{2}$.

Mesmo com o abrupto e inesperado fim do seu governo, todas as fontes consultadas - tanto primárias como secundárias - sugerem que a era Honecker foi caracterizada por considerável dinamismo econômico, estabilidade política - ainda

2 Cumpre reconhecer que o artigo privilegia uma perspectiva teórico-metodológica de pesquisa histórica. Procurase um mínimo de originalidade ao considerar prioritariamente as fontes primárias - isto é, documentação político-diplomática legalmente resguardada em um significativo arquivo brasileiro. Paralelamente, vale destacar que a literatura disponível sobre a queda do muro de Berlim, tanto a publicada no Brasil quanto no exterior, registra de forma abrangente o acontecimento e principalmente suas implicações. Porém, pouquíssima literatura fundamentase em pesquisa com documentação de arquivos históricos. Convém adiantar, também, que o texto não coloca como problema a questão das relações bilaterais do Brasil com a RDA, com a RFA ou com a Alemanha reunificada - essa tarefa fica pendente para futuras investigações. Mesmo assim, entende-se que os depoimentos dos diplomatas brasileiros são importantes e merecem ser trabalhados, inclusive para uma melhor compreensão do fenômeno e para complementar o conhecimento científico disponível sobre um acontecimento de interesse virtualmente global. 
que marcadamente despótica - e significativos avanços culturais, sociais, científico-tecnológicos e desportivos em um país de 110000 quilômetros quadrados, com uma população de 16 milhões de habitantes (em 1990) e com um produto per capita de aproximadamente US\$ 8000 - valor inferior ao da RFA, porém entre os mais altos do campo socialista e comparável ao de países como a Grécia, Portugal e Espanha. Para muitos, inclusive para os diplomatas brasileiros lotados em Berlim Leste, a RDA era - ou parecia ser - um dos mais bem-sucedidos exemplos de socialismo realmente existente no Leste Europeu.

Um dos principais pilares da era Honecker foi a sua estratégia econômico-social. Apoiados em pesados subsídios estatais - de aproximadamente 60 bilhões de marcos anuais em 1988 -, os dirigentes comunistas acreditavam firmemente na possibilidade de manter a expansão do consumo, da produtividade e, de modo geral, a expansão do produto (entre 4 e $5 \%$ no Plano Qüinqüienal 19861990). Contudo, relatórios procedentes da embaixada brasileira em Berlim Leste sugerem que desde 1987 era cada vez mais difícil lograr alcançar as ambiciosas metas e evitar os graves desequilíbrios macroeconômicos (dívida externa, déficit comercial, baixo crescimento da Renda Nacional Produzida) (ARQUIVO HISTÓRICO DO MINISTÉRIO DAS RELAÇÕES EXTERIORES, 1988). Mesmo assim, a política econômica germano-oriental continuou sendo rigidamente enquadrada dentro da ortodoxia socialista, negando-se a aceitar inclusive as propostas de reforma econômica - Perestroika ou reestruturação dentro do socialismo - impulsionadas na União Soviética por Mikhail Gorbachev (MCADAMS, 1988; ADOMEIT, 1990; MONIZ BANDEIRA, 2001).

Paradoxalmente, a negativa de impulsionar reformas econômicas (e políticas) na RDA era sustentada no seu privilegiado relacionamento com a RFA, que se expressava fundamentalmente na "concessão de empréstimos a fundo perdido, doações de máquinas e equipamentos modernos, manutenção das principais estradas de rodagem e facilidades no acesso de produtos da RDA ('made in Germany') ao Mercado Comum Europeu" (ARQUIVO HISTÓRICO DO MINISTÉRIO DAS RELAÇÕES EXTERIORES, 1989a). Outras fontes sugerem que Bonn terminava oxigenando - com subsídios de aproximadamente três bilhões de marcos ocidentais - $\mathrm{o}$ sistema produtivo germano- oriental e retardando a introdução de reformas econômicas que, se tomadas no momento certo, poderiam ter permitido a continuidade políticoinstitucional da RDA na década de 1990.

Cumpre acrescentar que Honecker terminou rejeitando não somente a introdução de reformas econômicas na RDA como também questionou a Perestroika impulsionada por Gorbachev na própria URSS e em outros países socialistas - o que irritou profundamente o líder soviético e alentando os grupos ortodoxo-stalinistas do bloco, particularmente na Tchecoslováquia, Romênia, Bulgária e Cuba (MCADAMS, 1988).

Ainda que com uma estabilizada taxa de crescimento do produto, a realidade econômica da RDA no inicio de 1989 não parecia desesperada ou à beira do colapso. Percebe-se, sim, nas fontes documentais primárias a existência de um debate sobre a vinculação entre a formação de preços, a produtividade interna e a manutenção da política de subsídios na RDA. Em fevereiro de 1989, informou-se ao Itamaraty que "a discussão sobre a atual situação das subvenções estatais para fins de manutenção do atual nível de preços vem sendo aflorada pelas autoridades Governamentais deste país e debatida por professores, sociólogos e economistas, com ampla divulgação na imprensa local". Na opinião dos diplomatas brasileiros parecia evidente e urgente a necessidade de elevar a produtividade dos trabalhadores e os investimentos para manter o padrão de consumo do país e os preços dos alimentos, aluguéis e tarifas de serviços (ARQUIVO HISTÓRICO DO MINISTÉRIO DAS RELAÇÕES EXTERIORES, 1989b).

No campo político, a estabilidade da era Honecker era apoiada pela hegemonia do SED e seus parceiros. Até 1989 a oposição política era praticamente inexistente e a sociedade civil germanooriental parecia anestesiada ou desestruturada. Simultaneamente um extenso aparelho policial encabeçado pelo Serviço de Segurança do Estado - o tristemente célebre Stasi - assegurava o controle e a vigilância da população, chegando ao extremo de quebrar lealdades familiares, profissionais e principalmente político-administrativas. Em um país onde praticamente todos os habitantes acabavam sendo funcionários públicos, a lealdade ao partido (SED), ao Estado (RDA), ao líder (Honecker) e eventualmente à polícia política (Stasi) era condição sine qua non para progredir na carreira profissional ou simplesmente para continuar sobrevivendo. Tal si- 
tuação era tolerada pelos homens mais velhos, que experimentaram a rudeza do nazismo e da guerra total, porém era claramente aborrecida e repudiada pelos jovens, que enxergavam poucas perspectivas futuras de desenvolvimento humano integral e, além disso, eram continuamente estimulados pela propaganda econômico-consumista e política ocidental, em geral, e da RFA, em particular.

Assim, até as celebrações do $1^{\circ}$ de maio de 1989 a documentação diplomática procedente de Berlim Leste não informava ou identificava qualquer sintoma de decomposição interna no governo Honecker. O que era, sim, aguardado, era a substituição do chefe de Estado, após quase vinte anos de governo, devido fundamentalmente à progressiva deterioração da sua saúde. Com efeito, de informações obtidas no meio diplomático acreditado na capital germano-oriental, o embaixador brasileiro Ernesto Ferreira de Carvalho relatou, em 14 de setembro, que "Honecker encontra-se já fora de perigo de vida, mas, ao que parece, com câncer, o que lhe daria um prazo de vida limitado, que poderia ser de 02 meses a 02 anos" (ARQUIVO HISTÓRICO DO MINISTÉRIO DAS RELAÇÕES EXTERIORES, 1989c) ${ }^{3}$. Acrescente-se que os dois nomes mais cotados para substituí-lo eram Egon Krenz e Günter Schabowski. O primeiro qualificado como "um seguidor da política atual, anti-reformista, mais fechado e duro que o próprio Honecker, e sem a figura carismática daquele", isto é, um comunista tradicional de 52 anos. O segundo, de 60 anos, jornalista, casado com cidadã soviética e "amigo do grupo ligado a Gorbatchov, de cujas idéias é favorável”, isto é, um comunista reformista ou gorbachovista (ADOMEIT, 1990).

\section{ERICH HONECKER NO QUADRAGÉSIMO ANIVERSÁRIODA REPÚBLICA DEMOCRÁ- TICA DAALEMANHA: O "BAILE DAILHA FISCAL" DO PARTIDO SOCIALISTA UNI- FICADO DAALEMANHA?}

A RDA foi fundada em 7 de outubro de 1949 e, com o motivo do quadragésimo aniversário, as

\footnotetext{
3 Após a queda do muro de Berlim, Erich Honecker procurou refúgio na URSS, até que Boris Yeltsin determinou, em 1992, sua extradição para a Alemanha, a fim de responder a processo judicial por abusos e desmandos durante seu longo governo. Contudo, em 1993, por razões humanitárias, acabou sendo libertado. Honecker passou os últimos dias de vida em Santiago de Chile, onde morava sua segunda filha, e faleceu naquele país em maio de 1994.
}

autoridades do Partido Socialista Unificado da Alemanha estavam empenhadas em realizar uma importante demonstração de prestígio, poderio e influência. Igualmente as comemorações prenunciavam a inevitável mudança na liderança e o fim da era Honecker - o que certamente era de interesse do partido, do Estado, da sociedade germano-oriental e de atores internacionais com vínculos e interesses na Europa Central - particularmente da URSS de Gorbachev e da RFA do chanceler Helmut Kohl (MCADAMS, 1988; ADOMEIT, 1990).

Contudo, a partir de 2 de maio de 1989, um conjunto de acontecimentos dentro da RDA e fora do país terminaram - intencionalmente ou não comprometendo não somente os festejos do aniversário pátrio, como também forçando a renuncia de Honecker, a queda do muro de Berlim, o colapso do Estado dos operários e camponeses e, finalmente, a reunificação da nação alemã.

Hertle (2001), Moniz Bandeira (2001) e Gaddis (2005), entre muitos outros autores, bem como a documentação enviada ao Itamaraty desde a representação brasileira lotada em Berlim Leste, coincidem em afirmar que os acontecimentos supracitados iniciaram naquele 2 de maio com a decisão do governo reformista da Hungria de desmantelar as estruturas militares e - virtualmente abrir sua fronteira comum com a Áustria. A notícia da abertura da fronteira austro-húngara bem no inicio das férias de verão na Europa impulsionou espontaneamente um grande número de jovens - e posteriormente de famílias completas germano-orientais a tentar o êxodo para a RFA ${ }^{4}$. Ainda que Berlim Leste tenha reagido e protestado, Budapeste decidiu adotar um enfoque essencialmente humanitário diante do fluxo de refugiados procedentes da RDA - algo semelhante aconteceu nas semanas seguintes com a entrada de germano-orientais nas embaixadas da RFA em Praga e Varsóvia. E em poucos dias o êxodo dos alemães tornou-se massivo e dramático para um país de 16 milhões de habitantes. Observe-se que até dezembro de 1989 aproximadamente 350000 germano-orientais, principalmente jovens em ida-

\footnotetext{
4 Parece importante registrar que a política imigratória da RFA com relação aos germano-orientais era extremamente laxa, e a concessão da cidadania germano-ocidental era praticamente automática para os habitantes da RDA que conseguiam ingressar em território da RFA.
} 
de produtiva, abandonaram seus lares e trabalhos provocando graves conseqüências econômicas, políticas, sociais, ideológicas e principalmente familiares.

Segundo a documentação diplomática brasileira, foi até 8 de setembro de 1989 que o governo de Honecker teria reconhecido a existência do êxodo - e qualificando-o de tentativa para desestabilizar a RDA e empanhar as comemorações programadas para 6 e 7 de outubro. Na avaliação preliminar dos diplomatas brasileiros, "esses acontecimentos vêem causando muita intranqüilidade à população da RDA, especialmente de Berlim, e propiciaram a recente formação de um grupo político, o 'Neues Forum', constituído por cerca de cem intelectuais e profissionais diversos de todo o país, a maioria deles pertencente à igreja evangélica, que se propõem estabelecer um novo tipo de diálogo com o governo. Caso as autoridades locais tolerem a existência de tal agremiação, que, em princípio, encontra respaldo na lei, o 'Novo Fórum' será o primeiro grupo político de oposição na história da RDA, embrião talvez de um partido político de oposição [...]. Somam-se a esses fatos, com mais um elemento desestabilizador, as especulações crescentes sobre o estado de saúde de Erich Honecker, que há mais [de] dois meses não aparece em público" (ARQUIVO HISTÓRICO DO MINISTÉRIO DAS RELAÇÕES EXTERIORES, 1989d).

Em comunicações subseqüentes, a questão do êxodo de germano-orientais continuou sendo abordada. Assim, em 6 de outubro, isto é, na véspera das comemorações do quadragésimo aniversário da RDA, o embaixador brasileiro ponderou que era "dramática e constrangedora" a saída de jovens "deixa[ndo] para trás emprego, casa, familiares e amigos, abandonando um país economicamente bem sucedido, o único, aliás, ao que parece, entre os socialistas, sem miséria e sem fome, mas sem liberdade, sem garantias, sem perspectivas de melhor padrão de vida" (ARQUIVO HISTÓRICO DO MINISTÉRIO DAS RELAÇÕES EXTERIORES, 1989e).

Cumpre acrescentar que a dramática emigração de significativa parcela da população também terminou provocando uma rápida e enérgica reação da até então anestesiada sociedade civil germano-oriental. Particularmente relevante para os fins deste artigo é constatar o surgimento de organizações sociais e políticas anteriormente des- conhecidas no país, com destaque para o denominado "Novo Fórum", fundado em 9 de setembro de 1989, com propósito de impulsionar reformas socialistas dentro da RDA (FOUNDING APPEAL OF THE NEW FORUM, 1994). Igualmente importante e inédito - pelo menos desde a (subjugada) insurreição popular de 1953 - foi o inicio, em setembro de 1989, de uma onda de protestos urbanos, com epicentro nas cidades de Leipzig e Dresden, e auspiciados pelas igrejas evangélicas e católicas.

Incentivados (ou não) por Bonn, o simultâneo êxodo migratório com destino à RFA, o surgimento de grupos políticos oposicionistas, a onda de protestos e os preparativos do quadragésimo aniversario da fundação do país marcados para 6 e 7 de outubro colocaram o governo de Honecker - e o próprio regime comunista - em uma delicada encruzilhada com duas (ou três) alternativas: 1) negociar com a oposição, procurando-se uma saída democrática; 2) reprimir a oposição - seguindo o exemplo da denominada solução chinesa, isto é, o violento enquadramento da oposição e a transformação do país em uma gigantesca cadeia - e/ou 3) derrubar Honecker com um golpe palaciano para impor um acelerado programa de reformas segundo o modelo gorbachovista. Cumpre acrescentar que, em 26 de setembro de 1989, Honecker teria autorizado o uso da força - isto é, uma cruenta solução chinesa em alusão ao massacre na praça de Tiananmen, em Beijing, em 4e5 de junho de 1989 - após os festejos do aniversário da RDA (KRAMER, 1999).

Para o embaixador Ernesto Ferreira de Carvalho, as comemorações da fundação da RDA terminavam sendo o equivalente do "Baile da Ilha Fiscal" da monarquia brasileira em 1889. Enquanto o país estava no meio de uma gravíssima convulsão e sua própria existência como Estado independente começava a ser colocada em dúvida, a liderança da SED festejava as conquistas - reais ou imaginarias - da pátria. Assim, em 6 de outubro de 1989, em discurso perante os incondicionais, Honecker manifestou, por exemplo, que a RDA era um "posto avançado da paz e do socialismo". Profética ou ilusoriamente garantiu que "a RDA cruzará o umbral do ano 2000 com a certeza de que o socialismo é o futuro". Reiterou sua rejeição a uma eventual reunificação da nação alemã, criticou o revanchismo e o intervencionismo de Bonn, condenou o ressurgimento do nazismo na RFA, sublinhou as conquistas do bloco socia- 
lista e da China, advertiu contra aqueles que duvidavam da força e das vantagens do socialismo, e concluiu afirmando candidamente que "em sua quinta década, o Estado dos operários e camponeses alemães continuará comprovando - mediante suas ações para o bem-estar do seu povo e mediante seus esforços pela paz, segurança e cooperação internacional - que sua fundação em Outubro de 1949 foi um divisor de águas na história do povo Alemão e da Europa" (ERICH HONECKER ON THE 40 ${ }^{\mathrm{TH}}$ ANNIVERSARY OF THE GDR, 1994).

Ao mesmo tempo, a presença de Gorbachev em Berlim e suas recomendações às lideranças do SED - alertando-os de que "Quem chega tarde demais, a vida castiga" (Gorbachev apud MONIZ BANDEIRA, 2001, p. 153) - não logrou conter a repressão militar, especialmente em Dresden, onde mais de 1000 pessoas foram arrestadas em 7 de outubro, e muitas delas foram enviadas para a tristemente recordada prisão da Stasi em Bautzen (ALTMANN, 1989) ${ }^{5}$. Contudo a jornada-chave foi em Leipzig, em 9 de outubro (HERTLE, 2001). Muitos realmente temiam que, após o fim dos festejos do aniversário da RDA e do retorno das delegações estrangeiras aos seus países de origem, uma repressão violentíssima da oposição desarmada - isto é, a aplicação da temida solução chinesa - fosse efetivamente realizada na cidade-berço dos protestos contra o SED. Observe-se que Honecker tinha assinado, em 26 de setembro, ordens diretas e secretas para esmagar os revoltosos. E existiam persistentes rumores de que um novo Tiananmen aconteceria em Leipzig. Kramer informa que as forças de segurança germano-orientais destacadas naquela cidade tinham sido instruídas nos seguintes termos: "Camaradas: de agora em diante se trata de uma guerra de classes [sociais]. Hoje [9.10.1989] tudo será decidido: ou eles ou nós. A vigilância de classe é essencial. Se os cassetetes não são suficientes, usem as armas de fogo. [Se vocês encontrarem crianças], isso é ruim para eles. Nós temos as armas, e não as temos em vão!" (KRAMER, 1999, p. 571).

Um apelo, in extremis, das autoridades soviéticas, junto com o chamado à prudência da igreja luterana local, terminou impedindo o massacre dos

5 O documento em aprecio é o relato dos sofrimentos experimentados pelo senhor Steffen Altmann, preso e submetido a todo tipo de abusos e humilhações. manifestantes em Leipzig. Assim, a solução chinesa, vivamente respaldada por Honecker e outros integrantes da linha dura do SED, foi definitivamente desativada como alternativa para enfrentar os problemas do país. E uma semana depois, em 17 de outubro, foi anunciada a renúncia de Honecker, por razões de saúde - e obviamente por incompatibilidade com a dramática realidade política, social e econômica do país ${ }^{6}$. Para os diplomatas brasileiros, a saída de Honecker era algo esperado e natural ${ }^{7}$. Mesmo assim, o grupo linha dura conseguiu impor uma saída elegante para seu líder e confirmar um dos seus integrantes, Egon Krenz, há muito tempo considerado herdeiro natural, na Secretaria-Geral do SED.

\section{O INTERLÚDIO DE EGON KRENZ, A QUE- DA DO MURO DE BERLIM E O ESBOROA- MENTO DO SOCIALISMO REALMENTE EXISTENTE NA RDA}

Resultado de um evidente compromisso político no interior do Politbüro entre o grupo linha dura (ou honeckeriano), de um lado, e os reformistas (ou gorbachovistas), de outro, o governo de Egon Krenz terminou sendo lembrado fundamentalmente por sua breve duração (de 17 de outubro a 14 de dezembro de 1989) e principalmente pela sua decisão pessoal de autorizar - na histórica noite de 9 de novembro de 1989 - a livre mobilidade dos germano-orientais, a abertura das fronteiras inter-alemãs e a tácita aceitação da queda do muro que dividia a capital da Alemanha ${ }^{8}$. $\mathrm{Na}$ opinião da Embaixada brasileira, "Egon Krenz foi sempre apontado como herdeiro presuntivo de Honecker e seu preferido, embora outros nomes em oportunidades diversas fossem igualmente citados. Como Honecker, vem da 'Juventude Livre

6 Junto com Honecker, foram "renunciados" Joachim Hermann, responsável pela área político-ideológica, e Günter Mittag, o assim chamado "czar da economia" da RDA (HERTLE, 2001).

7 Em 6 de outubro, o embaixador brasileiro em Berlim Leste informou ao Itamaraty que "há sinais evidentes de que Honecker deverá abandonar suas funções imediatamente após os festejos de hoje e amanhã. Os médicos que o operaram [...] diagnosticaram uma total degeneração de seus órgãos internos" (ARQUIVO HISTÓRICO DO MINISTÉRIO DAS RELAÇÕES EXTERIORES, 1989f).

8 Hertle (2001) informa que, paralelamente, o SED negociava um urgente pacote de assistência econômica com a RFA em troca da abertura gradual das fronteiras entre ambos Estados alemães. 
Alemã', onde iniciou sua carreira política. É homem de 52 anos - e isso conta a seu favor - mas aparenta mais idade talvez por ser diabético. Contra ele é lembrado que na sua recente viagem à China, onde chefiou a delegação da RDA nos festejos do $40^{\circ}$ aniversário da Revolução Chinesa, fez pronunciamento em favor das medidas de repressão tomadas pelas autoridades daquele país. [...] No círculo diplomático há quem diga que o atual chefe do governo durará pouco, marcando passo para substituição por alguém mais identificado com as propostas de reforma reclamadas em diversas camadas da sociedade da RDA e de confiança do povo" (ARQUIVO HISTÓRICO DO MINISTÉRIO DAS RELAÇÕES EXTERIORES, 1989g) ${ }^{9}$.

Oficialmente Krenz foi nomeado para o cargo de chefe de Estado na Câmara do Povo - isto é, o Parlamento da RDA - em 24 de outubro. No discurso de posse o novo governante reafirmou a vigência do artigo $1^{\circ}$ da Constituição do país em que se expressava, dentre outras coisas, que "a RDA é um Estado socialista dos operários e dos camponeses. É a organização política dos trabalhadores da cidade e do campo, sob a liderança da classe trabalhadora e seu partido marxista-leninista" (KRENZ, 1989). Em outras palavras, Krenz entendia que o SED deveria continuar com a presunção de ser a vanguarda iluminada do país. Igualmente alertou que "ninguém deveria desenhar falsas conclusões a partir do desenvolvimento político da RDA. A República Democrática da Alemanha é um Estado socialista soberano, e tudo o que acontece aqui é resultado da decisão soberana do nosso país e seus cidadãos. As propostas e 'sugestões' da OTAN objetivando a abolição do socialismo por meio de reformas continua não tendo chance!" (idem). Mesmo assim, reconheceu a urgente necessidade de impulsionar políticas públicas para conter o êxodo para a RFA, bem como atender as reivindicações sociais e políticas mais imediatas, dentre outras, conceder o direito de livre circulação - isto é, de viajar ao exterior sem restrições governamentais -, eleições livres, liberdade de imprensa, respeito aos direitos humanos, mudanças na política econômica. O próprio futuro da RDA como Estado soberano estava comprometido.

\footnotetext{
9 No mesmo documento em apreço, Carvalho ponderou que "a saída de Honecker eram favas contadas, surpreendendo apenas pelas rapidez com que o Comitê Central agiu e anunciou sua decisão" (ARQUIVO HISTÓRICO DO MINISTÉRIO DAS RELAÇÕES EXTERIORES, 1989g).
}

Em tal sentido, e com muita razão e perspicácia, indagava-se o embaixador brasileiro duas semanas antes da queda do muro: "E agora? Até que ponto Krenz poderá resistir às forças oposicionistas, às reformas [gorbachovistas], se, como se diz, essa é a razão de ser de sua escolha. Mas, se vencido pelas circunstâncias, recolher e aplicar as propostas aceitas e em vigor em outros países vizinhos socialistas [ainda governados por comunistas de linha dura], qual será o futuro da RDA: subsistirá com[o] Estado soberano ou, sem a individualidade nacional própria, terá questionada sua existência política em favor da reunificação alemã - tabu e pesadelo de tantos. Caso contrário, fechando-se solitária, qual sua capacidade de sobrevivência na Europa de 1992, unida e interdependente. Curioso saber qual a preferência da RFA. A reunificação ou a existência da RDA como um apêndice econômico seu, corredor de seu comércio para os países do leste. Tudo isso e mais do que isso significa em poder políticoem troca de 3 bilhões de dólares anuais em doações e pagamentos diretos e indiretos além de favores tarifários que têm permitido aos produtos da Alemanha do Leste chegar aos mercados da Comunidade [Econômica Européia]. Como bem observou um comentarista internacional, Alem[a]nha, por ora a República Federal Alemã, obteve na paz o que não ganhou em duas guerras mundiais: riqueza, prestigio, hegemonia. Haveria ainda uma terceira hipótese - como as outras duas objeto de futurologia - que não é tese nova mas vai ganhando adeptos, a da transformação da RDA em Estado tampão, com neutralidade garantida aos moldes da Áustria" (ARQUIVO HISTÓRICO DO MINISTÉRIO DAS RELAÇÕES EXTERIORES, 1989h).

$\mathrm{Na}$ verdade rapidamente tornou-se evidente que Egon Krenz não tinha os necessários argumentos políticos ou econômicos para legitimar seu governo e conquistar a obediência e aquiescência dos cidadãos germano-orientais. Sem o apóio econômico-financeiro soviético - devido à crise na própria URSS -, sem poder reprimir a população e com forte pressão doméstica (e externa), Krenz tinha a difícil tarefa de tentar convencer os cada vez mais céticos compatriotas sobre a necessidade de manter a confiança no projeto do socialismo renovado. Em tal sentido, o chefe de Estado procurou o apóio diretamente dos operários e camponeses, encontrando alguma acolhida e ressonância. Porém, a dramática realidade do país tam- 
bém demandava ações concretas para apaziguar os protestos e manifestações contrarias à hegemonia do SED.

De fato não pararam de crescer e de se disseminar em toda a geografia nacional os protestos contra Krenz, contra o SED e, em certos casos, contra a própria existência da RDA. Qual verdadeiro tsunami oposicionista, em 4 de novembro de 1989, uma inédita manifestação de 500000 pessoas expressou seu repúdio diante do regime comunista. Cumpre acrescentar que, desde 1953, não se registravam protestos de tal magnitude no país. Os manifestantes eram homens e mulheres do povo, intelectuais, e até membros reformistas (ou gorbachovistas) do próprio governo, dentre outros.

Em 8 de novembro, os 18 membros do Politbüro do SED - muitos destes com idades acima dos 70 anos - colocaram seus cargos à disposição. Ficou acertado que as vagas deveriam ser preenchidas por lideranças reformistas (ou gorbachovistas), encabeçadas pelo prefeito de Dresden Hans Modrow, que assumiu o posto de Primeiro-Ministro (em 17 de novembro) e posteriormente de Primeiro-Secretário do partido.

No dia seguinte, Krenz aprovou a minuta da futura lei de viagens - que deveria passar a vigorar formalmente após sua aprovação no Parlamento. Porém, no momento do anuncio da lei, o porta-voz Günter Schabowski informou, ao vivo, que a reforma migratória entraria imediatamente em vigor - isto é, que a partir daquela mesma noite a RDA permitiria a livre mobilidade dos cidadãos em todas as fronteiras do país, bem como nos pontos de controle do muro de Berlim ${ }^{10}$. E, diante da imediata aglomeração de mais de 100000 berlinenses orientais nas adjacências do muro, Egon Krenz terminou endossando o anúncio, in-

10 A transcrição do anúncio de Günter Schabowski é a seguinte: "As viagens privadas ao estrangeiro se podem autorizar sem apresentação dos requerimentos previamente existentes - seja motivação da viagem ou lugar de residência. As autorizações serão emitidas sem delongas." E diante da pergunta de um jornalista sobre a data de entrada em vigor do projeto, Schabowski respondeu: "Passa a vigorar, segundo minhas informações, imediatamente". Finalmente acrescentou que "as viagens de duração permanente podem realizar-se em todos os postos fronteiriços da RDA para a RFA e Berlim Ocidental, respectivamente" (Schabowski apud HERTLE, 2001, p. 157-158). clusive para evitar maior confusão e eventuais acidentes $^{11}$.

Testemunha direta dos dramáticos e emocionantes acontecimentos em Berlim o embaixador Carvalho informou ao Itamaraty o seguinte: "Acabo de passar pelas duas fronteiras, a de Bornholmer Strasse e a Checkpoint Charlie onde vi movimento inusitado de viaturas, a caminho do outro lado e de centenas de pessoas, curiosos, na sua maioria, acompanhando o movimento" (ARQUIVO HISTÓRICO DO MINISTÉRIO DAS RELAÇÕES EXTERIORES, 1989i) ${ }^{12}$. Alguns dias depois, Carvalho enviou ao Itamaraty um telegrama mais ponderado, ilustrativo e refletido dos acontecimentos. E devido à sua extraordinária relevância histórica e analítica, o documento merece ser apreciado e citado por extenso: "O muro caiu, já o disse, mesmo se seu esquálido esqueleto de concreto continua de pé, a enfear e dividir a cidade, ao longo dos seus $162 \mathrm{~km}$ de extensão. Sabe-se, a propósito, que a Porta de Brandenburg, que a todo momento se espera seja desobstruída, destruindo-se o muro em sua volta, só não foi ainda metaforicamente aberta, por receio das conseqüências dramáticas com o ir e vir de enormes massas de gente.

É sabido que o muro data de 1961 - mas a sua história não tem cabimento aqui - sendo o marco vivo e concreto da divisão de políticas, de forças opostas, de interesses contrários e de ideologias diferentes, e, por isso mesmo, o monumento mais dramático da Guerra Fria e o mais gritante e obvio argumento de propaganda anti-comunista. Mas, ademais, e sobretudo, foi a única maneira encon-

11 Segundo Hertle (2001), algumas autoridades da RDA e da URSS acreditavam na possibilidade de recuperar o controle e a lógica do muro - o que, finalmente, tornou-se inviável e irreversível. Tecnicamente, o muro começou a ser desmantelado pelas autoridades germano-orientais em 13 de junho de 1990 - concluindo-se os trabalhos em novembro de 1991. Em $1^{\circ}$ de julho de 1990 todos os postos de controle foram formalmente fechados. Atualmente existem pequenos trechos do muro preservados por motivos histórico-culturais.

12 Cumpre acrescentar que o diplomata encerrou o documento em aprecio com a seguinte frase: "Uma última observação: em nenhum momento, quer os partidos políticos, quer os manifestantes, nas diferentes cidades da RDA exigindo reformas polític[as] e econômicas, se referiram à reunificação da Alemanha. Ao contrario todos tem enfatizado a importância de existir dois Estados livres e soberanos". 
trada pela então recém criada RDA para estancar a hemorragia que ela sofria com a emigração para a RFA, via Ost-Berlin, de seus melhores e mais qualificados cidadãos.

Entendendo-se as super-potências em assuntos maiores, prevalecendo a 'Detente' à Guerra Fria, reconhecidas as suas posições e respeitadas as áreas de interesse e influência, o muro não tinha mais razão de ser, como a existência de regimes marxista-leninistas-ortodoxos no leste europeu, após a 'Glasnost e Perestroika', deixou de ter sentido.

Mas o muro de Berlim não é a Bastilha, que valia mais pelo seu significado político do que pela sua importância carcerária: o muro continuava a ter o papel importante de impedir a fuga de mão de obra qualificada... até que aconteceu o êxodo via Tchecoslováquia e Hungria. A partir daí tudo foi possível, e 'o establishment' se esboroou. A não ser pelo retorno ao 'status quo ante', que me parece de todo impossível, o desdobramento natural e normal a seguir é conhecido: às reformas políticas que se vão sucedendo a alta velocidade, logo virão as reformas econômico-financeiras, já em andamento promissor com a RFA e através desta com a CEE, com vistas à entrada de capitais, criação de 'joint-ventures', transferência de tecnologia e programas de ajuda, capazes de dar à economia da RDA o alento necessário para competir nos mercados internacionais - fora os do COMECON - e, principalmente, fixar seus nacionais em seu território" (ARQUIVO HISTÓRICO DO MINISTÉRIO DAS RELAÇÕES EXTERIORES, 1989j) ${ }^{13}$.

Entre a queda do muro (9-10 de novembro de 1989) e a apresentação do assim chamado "Programa de Dez Pontos", de Helmut Kohl, para a reunificação da Alemanha (em 28 de novembro do mesmo ano), Krenz e Modrow fizeram o maior esforço para preservar a hegemonia do SED e a própria subsistência da RDA como Estado soberano. Vale reconhecer-se que ambos os políticos germano-orientais continuavam apostando na via pacífica, negociada e eminentemente socialis-

13 Em termos globais, a queda do muro de Berlim foi considerada como um dos acontecimentos mais importantes da história mundial e da história da Guerra Fria (HALLIDAY, 1990; RUTLAND, 1999; MONIZ BANDEIRA, 2001; GADDIS, 2005). ta. Igualmente, o desafio era avassalador tanto no campo doméstico (garantir a governabilidade, impulsionar reformas econômicas, expandir a cidadania integral) quanto no campo externo (negociar com aliados socialistas, com a RFA de Kohl, e com outros países com vínculos na questão alemã, européia e global).

Observe-se que a assunção de Hans Modrow ao cargo de primeiro-ministro foi lograda por pressão de Gorbachev (ADOMEIT, 1990). Moniz Bandeira (2001) sugere que Modrow - então secretario distrital do SED na cidade de Dresden fazia muito tempo que era visto como o homem dos soviéticos na RDA para impulsionar as reformas. Ele era considerado honesto, sério, moderado e competente. Igualmente, é interessante acrescentar que o próprio cargo de primeiro-ministro, que anteriormente era basicamente simbólico ou cerimonial, foi reforçado e fortalecido com novas competências, capacidades e recursos. No seu discurso de posse, em 17 de novembro de 1989 , Modrow delineou reformas em cinco campos específicos: política, economia, educação, meio ambiente, e administração pública. No que diz respeito especificamente à reforma política ponderou que ela eventualmente forneceria "uma nova fundação para preservar e implementar uma política de auto-determinação para o povo da RDA" (MODROW, 1989). Modrow aceitava uma sensível aproximação com a RFA - inclusive a criação de uma comunidade contratual -, porém rejeitava "irrealistas e perigosas especulações sobre reunificação [alemã]" (idem).

Nos dias seguintes, Modrow anunciou seu gabinete de governo e boas intenções no que diz respeito à gestão das empresas estatais, à reestruturação das forças armadas e das agências de segurança do Estado, à constituição de comissões de inquérito para examinar acusações de abuso de poder, enriquecimento ilícito, corrupção e desmandos na era Honecker, às reformas constitucionais, à integração de uma mesa redonda com setores da oposição - em que se acordou a realização de eleições livres, diretas, pluralistas e secretas no mês de março de 1990 -, dentre outras questões urgentes. Contudo, todas essas propostas pareciam insuficientes e extemporâneas. Sobre isso, o embaixador do Brasil ponderou com franqueza e realismo: "A RDA, a meu ver, e de outros também, padece de males pré natalinos: sua legitimidade e identidade nacional, que serão questionadas e psicanalizadas pelos seus filhos, 
até a solução final, que só virá, num primeiro estágio, com eleições livres, diretas, secretas e honestas. Até lá seguirão as manifestações, trasanteontem em Berlim; anteontem, em Dresden e ontem como todas as segundas-feiras, há oito semanas, em Leipzig; traduzindo a consciência do pecado original, sem expiação, e inconscientemente, as humilhações e frustrações, sofridas ao longo de 40 anos, nos quais, a população alemã do leste, calada e solitária, de bom nível cultural e tradição universitária, foi tratada, qual rebanho de ovelhas, sem garantias nem direitos, sob o tacão da bota prussiana, que estava ali para defender as elites do partido, elas, sim com voz e vez, para anunciar as mentiras triunfalistas e se beneficiare os seus - de sua[s] vantagens e privilé-gios" (ARQUIVO HISTÓRICO DO MINISTÉRIO DAS RELAÇÕES EXTERIORES, 19891) ${ }^{14}$.

Em conseqüência, tornou-se evidente que, mais do que reformas dentro do socialismo ou a formação de um Estado socialista independente com uma economia socialista de mercado, a população germano-oriental estava interessada em incorporar-se rápida e irreversivelmente na RFA. Eis a relevância do então chanceler Helmut Kohl e de seu Programa de Dez Pontos para a Superação da Divisão da Alemanha e da Europa (de 28 de novembro de 1989).

\section{O PROGRAMA DE DEZ PONTOS DE KOHL E ACONTECIMENTOS SUBSEQÜENTES: BREVES APONTAMENTOS SOBRE AREU- NIFICAÇÃO DAALEMANHA}

Ainda que uma avaliação detalhada do processo de unificação alemã exceda o escopo deste artigo - inclusive porque muitas das negociações correspondentes foram realizadas fora das fronteiras da RDA e porque a documentação primária disponível no momento é muito limitada quanto ao assunto -, é importante, sim, destacar que na véspera da queda do muro de Berlim o chanceler Kohl (1982-1998) realizava visita de trabalho na Polônia. Ao saber dos acontecimentos voou para Berlim Ocidental e comemorou, in situ, o histórico acontecimento como todos os outros alemães. Contudo, Kohl foi além. Segundo a documenta-

14 Gale Stokes (1991) destaca que, além dos problemas estruturais da RDA, era necessário acrescentar aspectos intangíveis - e não menos importantes - tais como: ética, valores morais, ideais, direitos humanos, liberdade de escolha, religiosidade, multiculturalismo, dentre outros. ção do Itamaraty, na noite de 9 para 10 de novembro, ele "foi o único que se referiu à reunificação, assunto polêmico, tabu mesmo, sobretudo na RDA" (ARQUIVO HISTÓRICO DO MINISTÉRIO DAS RELAÇÕES EXTERIORES, 1989m). Iniciou-se assim um rápido processo que culminou em 3 de outubro de 1990, com a coroação da unificação da nação alemã.

Sob a perspectiva de Bonn e particularmente de Kohl, o evidente momento de fraqueza do SED poderia ser explorado para alcançar o antigo objetivo do chanceler Konrad Adenauer, qual seja, a reunificação do país com a incorporação do território da RDA na RFA. Naturalmente, a histórica conquista poderia gerar importantes dividendos político-eleitorais para seu partido - a União Democrata-Cristã (CDU, na sigla em alemão). Mesmo assim, o desafio da reunificação alemã era extremamente complexo, ao exigir não somente o apoio político em ambos os Estados alemães, como também a aquiescência das outras potências com vínculos e interesses na questão alemã, particularmente das quatro grandes potências vitoriosas da II Guerra Mundial (União Soviética, Estados Unidos, Grã-Bretanha e França, todas elas com direitos de ocupação vigentes em território alemão, em geral, e na cidade de Berlim, em particular) e de outros países da Europa central (particularmente, da Polônia e da Tchecoslováquia). Foi nesse contexto geral que o chanceler Kohl apresentou, no Parlamento da RFA, em 28 de novembro de 1989, seu "Programa de Dez Pontos para Superar a Divisão da Alemanha e da Europa" (KOHL, 1989a).

Resumidamente o programa em questão propunha desenvolver um esforço coordenado em três níveis paralelos e interdependentes: o interalemão, o continental ou europeu, e o global. No nível inter-alemão, Kohl reivindicava uma sensível aproximação em todas as áreas com a RDA. Subentendia-se que o novo governo germano-oriental deveria submeter-se a um irreversível processo de democratização e de outras transformações estruturais tanto econômicas (economia social de mercado) como sociais (direitos humanos, cidadania, liberdades). O chanceler da RFA acreditava na constituição inicial de uma confederação entre ambos os Estados alemães, posteriormente no surgimento de uma federação, e finalmente na reunificação - em um prazo de dois a três anos. No nível europeu, a proposta de Bonn insistia na construção da Casa Comum Européia, 
na continuidade da agenda de Helsinque e, principalmente, na plena vigência da integração regional - inclusive com a perspectiva de criar a União Européia em 1992. E, simultaneamente, Kohl afirmava a necessidade de consolidar os entendimentos no sentido Leste-Oeste, reduzir o risco de uma guerra nuclear e manter a aderência da futura Alemanha unificada no bloco ocidental. Cumpre acrescentar que trabalhar simultaneamente nos três níveis era fundamental e iniludível. Na opinião do chanceler germano-ocidental, era possível conciliar os interesses de todos os atores, mediante a execução de um processo de negociação prudente, razoável e equilibrado - além de estar disposto a investir massivos recursos financeiros na RDA e nos países vizinhos, isto é, a denominada diplomacia do Deutschmark.

Naturalmente, o Programa de Dez Pontos de Kohl provocou importantes reações na RDA. Inclusive desde antes do anúncio do plano, parcela significativa da população adotou a idéia da reunificação, como alternativa para conseguir resolver definitivamente a divisão do país - e conseguir uma rápida incorporação ao primeiro mundo. Nas faixas dos protestos - que anteriormente afirmavam "nós somos o povo" - passou a predominar o lema "nós somos um povo" (MONIZ BANDEIRA, p. 159; 171), isto é, a nação alemã que deveria reconstituir-se após quatro décadas de espera.

Contudo, para os governos de Berlim Leste, Moscou e outras capitais européias - preocupadas com o eventual ressurgimento do assim chamado perigo alemão - o Plano de Dez Pontos não era plenamente satisfatório. O embaixador Carvalho informou a Brasília que a RDA aceitava discutir o aprofundamento da cooperação inter-alemã, porém rejeitava a proposta central de uma eventual reunificação. Nessa linha, o diplomata brasileiro ponderou o seguinte: "Depreende-se dessas declarações que a RDA não quer abrir mão de dois preceitos básicos: socialismo e independência [...]. No entanto, no último dia 27 [de novembro], o tema da reunificação figurou pela primeira vez nas manifestações que se realizam em frente à Igreja de São Nicolaus, em Leipzig e em outras cidades do país" (ARQUIVO HISTÓRICO DO MINISTÉRIO DAS RELAÇÕES EXTERIORES, 1989n).

Paralelamente, Gorbachev questionou duramente o anúncio do Programa em conversa particular com o então Ministro das Relações Exterio- res da RFA, Hans-Dietrich Genscher. Para o Chefe do Estado soviético a proposta de Kohl terminava sendo um virtual e inaceitável ultimato contra um Estado alemão igualmente soberano, independente e membro do Pacto de Varsóvia - além de desconhecer os direitos de ocupação das potências vencedoras da II Guerra Mundial. Categoricamente, Gorbachev observou que "qualquer aceleração artificiosa terminará comprometendo ou estorvando as significativas mudanças que estão sendo realizadas no processo de desenvolvimento dos Estados europeus, isto é, em uma área central da política global" (SOVIET PROTOCOL OF A CONVERSATION BETWEEN MIKHAIL GORBACHEV AND HANS-DIETRICH GENSCHER, 1989). E acrescentando o seguinte: "Penso que qualquer tentativa de aceleração artificial não seria interessante para o povo de cada Estado alemão. Os dois Estados alemães precisam reajustar suas relações dentro de um contexto de esforço para a estabilização, na base do equilíbrio e do respeito mutuo" (ibidem), alertando a Genscher que "hoje vocês estão agindo nesta linha [de ultimato] com a RDA, amanhã possivelmente com a Polônia, com Tchecoslováquia, e depois com a Áustria" (ibidem) $)^{15}$. Em síntese, Gorbachev advertiu categoricamente contra o que - sob a perspectiva do Kremlin - parecia uma abusiva intervenção de Bonn nos assuntos internos da RDA (ADOMEIT, 1990).

Mesmo assim, o processo de acelerada decomposição econômica e política da RDA - junto com a limitada assistência soviética disponível, em função dos próprios problemas internos na URSS não admitiam muitas alternativas. Observe-se, por exemplo, que na segunda semana de dezembro renunciou Krenz e posteriormente foi realizada total reestruturação do partido - que terminou sendo rebatizado com o nome de Partido do Socialismo Democrático (PSD).

Sobrou para Modrow a tarefa de fazer algo para evitar o colapso total e definitivo da RDA. Porém o tempo era muito curto, especialmente após a visita de Kohl ao país. Observe-se que em relato recentemente publicado sobre aquela viagem, Kohl destacou o seguinte: "A minha mais

15 Observe-se que inicialmente a opinião de Paris e Londres em relação à eventual reunificação da Alemanha também era de ceticismo e eventual oposição. 
crucial experiência no processo de unificação alemã foi a visita a Dresden em 19 de dezembro de 1989. Quando aterrissei com minha comitiva na irregular pista de concreto do aeroporto DresdenKlotzsche, rapidamente me pareceu claro: este regime está liquidado!" (KOHL, 1989b). Depois de falar brevemente para as massas sobre democracia, eleições, liberdade e unificação alemã, Kohl e Modrow assinaram um comunicado conjunto cujo ponto fundamental era o estabelecimento de uma comunidade contratual - decisão que, agora sabemos, representou o ponta-pé inicial da reunificação da nação e do Estado.

O ritmo e a forma do processo de reunificação aceleraram-se após o chamado às eleições de 18 de março de 1990 (HAMILTON, 1992). No processo em questão, cada um dos grandes partidos germano-ocidentais ajudou intensamente sua contraparte germano-oriental. E evidentemente a vinculação - real ou imaginaria - de ajuda econômica da RFA em troca de eleições livres terminou favorecendo os candidatos apadrinhados pelo chanceler Kohl. Assim, a denominada "Aliança pela Alemanha" triunfou com 48\% dos votos e 193 dos assentos no Parlamento. Acordos com outras organizações políticas favoráveis a uma rápida reunificação do país permitiram a nomeação de Lothar de Maizière como primeiro-ministro para um período de poucos meses até a incorporação da RDA à RFA - em 3 de outubro de 1990.

Convém reiterar que não é possível abordar detalhadamente o processo de negociação que resultou na reunificação do país, inclusive porque, após a nomeação de Lothar de Maizière, a RDA deixou de ser um ator ativo e passou a ser um sujeito de negociação entre grandes potências. Mesmo assim, é importante registrar a aprovação e a implementação dos dois tratados de unificação - o econômico, monetário e social (assinado em 18 de maio de 1990) e o político-administrativo (assinado em 31 de agosto de 1990) ${ }^{16}$-, bem como o denominado acordo " $2+4$ " (assinado em 12 de setembro de 1990), em que as quatro grandes potências vencedoras da última guerra aceita-

16 O Segundo Tratado de Unificação prevê a incorporação do território da antiga RDA, então reorganizado administrativamente em cinco novas províncias: MecklenburgVorpommen, Bradenburg, Sachsen-Anhalt, Sachsen e Thüringen - além do particular caso da região metropolitana de Berlim. ram a reunificação do país, e o acordo sobre o fim da ocupação do território germano-oriental e a manutenção da Alemanha unificada dentro da OTAN (assinado em setembro de 1990) ${ }^{17}$. Igualmente, é importante registrar a realização da primeira eleição pan-germânica em 2 de dezembro de 1990 - que confirmou Helmut Kohl como chanceler até o ano de 1998 (ARNOLD, 1991).

A avaliação geral da Embaixada brasileira sobre a etapa final do processo de negociação entre as grandes potências era positiva. Após o vital acordo Gorbachev-Kohl, nas montanhas do Cáucaso, entre 15 e 17 de julho de 1990, Carvalho ponderou o seguinte: "Tudo terminou bem. Foi um final feliz para a diplomacia de Kohl, e sobretudo de Genscher, que soube conduzir as negociações, com uns e outros, flexível e maneiroso, qual uma raposa, mas irredutível em tudo aquilo que pudesse vir a comprometer o objetivo maior [isto é, a reunificação na nação alemã]". (ARQUIVO HISTÓRICO DO MINISTÉRIO DAS RELAÇÕES EXTERIORES, 1990a) ${ }^{18}$. Acrescentou ainda que restavam problemas menores - porém não desprezíveis - tais como: a escolha da capital, direitos de propriedade, lei eleitoral, reconstrução nacional. Afortunadamente tais problemas, observou, eram "não de monta, porém, a ponto de retardar a eleição do novo Governo, único e geral, em dezembro próximo, data prevista para o desaparecimento da RDA, que passará a ser, segundo li alhures, apenas 'um pé de página' nos livros de história de amanhã" (idem).

E, com relação ao surgimento da Alemanha unificada como principal potência da Europa central, o diplomata brasileiro ponderou, por extenso: "Que virá a seguir, é a pergunta que muitos formulam. Desde logo, nasce uma potência econômic[a] e política de primeira grandeza, de grande densidade populacional para os termos europeus, de irresistível penetração econômicocomercial no leste-oeste, que a tornará a maior força no centro da Europa, capaz de alterar o tabuleiro político internacional. E depois? O alemão

17 Os três instrumentos supra-citados estão disponíveis no arquivo virtual denominado German History in Documents and Images (GERMAN HISTORICAL INSTITUTE, 2009).

18 Conferir também Adomeit (1990). 
de hoje: suas idiossincrasias, temperamento arrogante, capacidade de organização e disciplina arraigada, pouco difere daquele de 1914 e 1939 mas as condições, a conjuntura política, a situação econômica, o bem-estar social é todo outro, muito diferente e bem melhor. E de se ver, ainda, que a Alemanha Grande, de amanhã, não terá sido formada como a de 1914, com o espírito hegemônico imperial, vindo de Bismarck, nem o revanchista, de 1939, fruto de Versailles, é antes, e sobretudo, conseqüência de um processo democrático, de livre escolha, de compromissos com a liberdade, mercado livre e acatamento da lei. Na verdade a nova Alemanha unificada, é um presente da história, combinação de fatores exógenos, - fora do contexto em que as duas Alemanhas estavam inseridas - que as levaram a se unir num processo que teve sua própria dinâmica - tais, as reformas avançadas por Gorbachov - cuja seriedade e veracidade, Genscher soube ver e antecipar primeiro que todos - os levantamentos da Polônia e Hungria contra os regimes ditatoriais e, mais que tudo, o inconformismo e impaciência dos cidadãos da RDA que procuraram, por todos os meios, o caminho da liberdade. O que poderia ser apenas uma fuga do marasmo e opressão existentes, em busca de novos e melhores horizontes, tornou-se um levantamento nacional contra a divisão das Alemanhas" (idem) ${ }^{19}$.

Salvo melhor interpretação, pela sua lucidez, coerência e consistência, o parágrafo anterior dispensa comentários adicionais.

19 Cumpre acrescentar que Carvalho descartou a possibilidade de um eventual ressurgimento do assim chamado "perigo alemão", mas ponderou sobre a questão da ascensão do racismo como desafio social, econômico e humanitário. Nessa linha, argumentou o seguinte: "Com uma população de milhões de imigrantes espalhados de Londres ao Leste da Europa, mão-de-obra barata e útil e, ainda, mas não tanto, necessária [...] é muito natural [que] sobrevenham, num futuro próximo, problemas de convivência com os nacionais - mais ou menos graves - conforme sejam anos de abundância ou de escassez, que, aliás, aqui e ali, já vêm ocorrendo, embora minimizados. [...] Pode que por aí, sobretudo no que trata aos árabes, - mais contestatórios muito especialmente os radicais, os fundamentalistas, venham a surgir conflitos de efeitos multiplicadores que transcendam suas próprias fronteiras, com conseqüências políticas imprevisíveis" (ARQUIVO HISTÓRICO DO MINISTÉRIO DAS RELAÇÕES EXTERIORES, 1990a). Conferir também Hamilton (1992).

\section{CONSIDERAÇÕES FINAIS: WALTER MOMPEREACONFIRMAÇÃO DE BERLIM COMOCAPITALFEDERALDAALEMANHA REUNIFICADA}

"Entretanto, toques surgem desde [Berlim] Oeste: 'Queremos entrar!' Por um momento o foco de atenção mudou para o lado ocidental: [O prefeito Walter] Momper podia ser visto no meio da massa. Holofotes, microfones, câmeras. Seguidamente no teve mais paradas [nos pontos de controle do muro de Berlim]. E aproximadamente à 1:00 am [de 10 de novembro de 1989] começaram a correr. Um punhado de guardas [da RDA] protegem sua fronteira. As comportas se abrem, a barreira é levantada" (KRAUSHAAR \& RIEDLE, 1990).

Assim noticiou o jornal Die Tageszeitung o exato momento em que o muro deixava de existir como barreira física destinada a controlar a mobilidade humana entre os dois lados da cidade - e o prefeito Walter Momper era testemunha e participante dos festejos ${ }^{20}$. Para os fins deste artigo a figura de Momper é importante pelo seu persistente empenho em lograr não somente a reunificação da Alemanha, como também a rápida e fluida integração especificamente da cidade de Berlim, a sua confirmação como capital da Alemanha - o que não era tarefa simples - e a transformação produtiva, urbanística e política dessa metrópole ${ }^{21}$. Afinal, tratava-se da capital de uma

20 Militante do Partido Social-democrata da Alemanha (SPD), Momper assumiu a prefeitura de Berlim Ocidental no inicio de 1989 e concluiu seu governo em 1991. Simultaneamente, Momper também era presidente da Câmara Alta da RFA (1989-1990). Tratava-se de político experiente e bem relacionado no interior do sistema político germano. Observe-se que o prefeito erigiu-se no mais conhecido, insigne e combativo porta-voz da causa berlinesa. Ao mesmo tempo, não é possível descartar algum interesse político-eleitoral próprio ou partidário no ativismo e engajamento de Momper na política local, regional e nacional.

21 Outros assuntos polêmicos da época com relação especificamente à reunificação da cidade de Berlim eram os seguintes: o direito de propriedade dos imóveis nacionalizados no passado pelas autoridades da RDA, questões ambientais, serviços públicos (transporte, comunicações, limpeza urbana, desenvolvimento social), a massiva chegada de trabalhadores e refugiados procedentes de outras partes da RDA e de outros países (inclusive pedidos de asilo de soldados soviéticos destacados na região interessados em continuar morando na Alemanha), o ressurgimento do nazismo e as relações mais ou menos convergentes entre a política local (com um prefeito do SPD) e a esfera federal (com hegemonia do CDU). 
potência em ascensão localizada em pleno coração do continente europeu (ARNOLD, 1991).

Ainda que para alguns o estudo da reunificação da cidade de Berlim possa parecer corriqueiro, paroquial ou irrelevante, a documentação político-diplomática procedente da Embaixada - e posteriormente do Consulado-Geral - naquela cidade demonstra um grande e persistente interesse no assunto. Com efeito, durante todo o ano de 1990 os diplomatas brasileiros continuaram informando sobre tópicos especificamente berlinenses e seu particular processo de reunificação - após mais de 40 anos de divergências. Relatou-se, por exemplo, sobre o desmantelamento do check-point Charlie - e a ida para um museu da famosa guarita norte-americana, considerada como um dos símbolos mais relevantes da época da Guerra Fria. Também sobre a recuperação da plenitude institucional e político-administrativa da cidade anteriormente ocupada - ou protegida - por forças militares estrangeiras e sobre os preparativos para a primeira eleição pan-berlinense em muitas décadas. Ponderou-se que, "se no passado Berlim foi símbolo de um país e de um continente repartidos, hoje a cidade espelha com igual fidelidade a complexa trajetória de forças e circunstâncias que impulsionam o processo de reunificação. Esse papel vanguardista e aglutinador, que lhe impõe sua geografia física e histórica, adquire nova dimensão com a entrada em vigor do Tratado de União Econômica e Social entre dois sistemas frontalmente antagônicos. Se essa característica secular de Berlim não lhe credencia automaticamente para ser a futura capital da Alemanha unificada (como quer crer o prefeito de Berlim Ocidental, Walter Momper), não há dúvida tratarse de singular microcosmo dos desafios que o país como um todo vivenciará com crescente intensidade" (ARQUIVO HISTÓRICO DO MINISTÉRIO DAS RELAÇÕES EXTERIORES, 1990b).

Parece evidente, pois, a relevância e pertinência de explorar fundamentado em fontes documentais brasileiras recentemente desclassificadas o intenso debate para confirmar não somente a unificação física, social e psicológica da cidade, como também sua ascensão ao status de futura capital da Alemanha reunificada - reconhecendose inclusive as implicações decorrentes desta determinação em termos de inserção e prestígio internacional. Ao mesmo tempo, convém adiantar que o pleito em questão não era, em modo algum, de natureza narcisista. Pelo contrário, tratava-se da intensa luta entre atores políticos que procuravam garantir recursos orçamentários extra-ordinários para a capital do país, riqueza advinda de investimentos e salários do funcionalismo público federal, aprimoramento dos serviços públicos, visibilidade nacional e internacional, dentre outros $\operatorname{assuntos}^{22}$.

O debate em questão tornou-se particularmente intenso no segundo semestre de 1990. A Embaixada em Berlim Leste informou como pontos a favor da nomeação desta cidade a existência de certos preceitos legais e o apoio de lideranças políticas nacionais - tais como o Chanceler Helmut Kohl, o Primeiro-Ministro Lothar de Mazière, o Presidente Richard von Weizsäcker. Argumentouse igualmente que "mais do que uma compensação pelas agruras e privações impostas pela prolongada divisão da cidade, a recondução à condição de Capital Federal simbolizaria na consciência popular o coroamento do processo de restauração da identidade e dignidade nacionais. Haveria mesmo certa justiça histórica no fato de Berlim, cidade por tanto tempo submetida à ocupação aliada, viesse a corporificar o renascimento de uma soberania alemã democrática, capaz de exorcizar os demônios do passado nazista. [...] À cabeça desse movimento encontra-se o prefeito-governador de Berlim Ocidental, Walter Momper, que, em coordenação com sua contraparte oriental, Tino Schwierzina, vem insistindo na incorporação ao texto final do Segundo Acordo de Unificação a ser assinado até o final do ano, de referência ao status de Berlim como Capital Federal, para onde também a sede dos poderes executivo e legislativo deveria transladar-se" (ARQUIVO HISTÓRICO DO MINISTÉRIO DAS RELAÇÕES EXTERIORES, 1990c).

Momper e outros simpatizantes da proposta também apresentaram outras considerações para reforçar sua posição, dentre elas: 1) os investimentos para revitalizar a cidade teriam conseqü-

\footnotetext{
22 Considere-se, a propósito, o impacto e as conseqüências econômicas, políticas, sociais, urbanísticas e culturais advindas das transferências de capitais nacionais nos casos do Brasil (Brasília), Nigéria (Abuja), Myanmar (Naypyidaw), dentre outras. Em tal sentido, argumentouse que Berlim poderia desempenhar papel protagônico no cenário econômico, político, cultural, acadêmico e científico-técnico alemão e centro-europeu - inclusive servindo de sede de instituições regionais e comunitárias, além das embaixadas estrangeiras.
} 
ências em toda a região leste da Alemanha (isto é, na ex-RDA); 2) a cooperação entre as duas administrações da cidade tornar-se-ia exemplo e modelo para a reunificação nacional - em tal sentido, ambos os lados trabalharam de forma persistente e intensa para lograr o objetivo comum, inclusive no que diz respeito à fusão administrativa com Momper à frente da prefeitura geral da cidade ${ }^{23}$; e 3) após o encerramento formal, em 3 de outubro de 1990, da proteção/ocupação da região de Berlim por tropas das potências vencedoras da II Guerra Mundial seria possível identificar consideráveis espaços e imóveis para o desenvolvimento urbano local.

Contudo também existiam poderosas forças que resistiam à transferência da capital para Berlim. Os principais expoentes da recusa eram, obviamente, as autoridades dos estados de Renânia do Norte-Vestfália - onde se localiza a cidade de Bonn - e Baviera. No caso dos primeiros existia o receio de ficar "vazia e morta" após a partida da maior parte dos servidores públicos federais. $\mathrm{E}$ no caso dos segundos, aparentemente as críticas eram resultado do seu tradicional e conhecido sentimento federalista - e concomitantemente anticentralizador, antiprussiano. Igualmente poderosas eram as preocupações com os custos da transferência da capital - aproximadamente US\$ 55 bilhões em uma década - no meio de um caríssimo processo de reunificação nacional orçado em, no mínimo, US\$ 600 bilhões durante o decênio de 1990 (HAMILTON, 1992; WALKER, 1992). Não parece totalmente irracional, então, o modesto apóio da opinião pública alemã à transferência. Complementarmente, os críticos observaram que a presença de tropas soviéticas na região de Berlim - e no território da RDA - comprometia a viabilidade política e de segurança da capital da Alemanha reunificada. Finalmente, e não menos importante, era a questão do estoque de imóveis - para moradia, para escritórios e outros serviços, e para indústrias - disponíveis em Berlim para satisfazer as demandas da burocracia federal e de mais de 100 embaixadas de países do mundo todo.

\footnotetext{
23 A Prefeitura de Berlim Leste concordava plenamente com o esquema de Momper. Porém, a documentação diplomática brasileira comenta também o virtual vazio de poder e interlocução resultado do colapso do Estado germano-oriental. Em tal sentido, confirma-se a hipótese de que Berlim continuava sendo um micro-cosmos do processo de reunificação em nível nacional.
}

Momper rebateu de forma mais ou menos convincente todas as críticas. Segundo relato dos diplomatas brasileiros, o prefeito argumentou que "a incorporação, em condições justas e honrosas, das províncias à federação alemã dependeria de Berlim reconquistar suas prerrogativas institucionais do pré-guerra" (ARQUIVO HISTÓRICO DO MINISTÉRIO DAS RELAÇÕES EXTERIORES, 1990d). Nesse sentido, o prefeito colocava-se como defensor e protetor dos interesses de Berlim, em particular, e da região leste da Alemanha - isto é, a exRDA -, em geral. Valeu-se de sua afortunada condição paralela de presidente da Câmara Alta para apoiar a tese de Berlim, não se furtou de questionar as denominadas pretensões hegemônicas das grandes províncias ocidentais com relação ao território da ex-RDA e advertiu que "somente um Governo Central com luz e vigor próprios pode[ria] assegurar o equilíbrio federativo nas atuais circunstancias marcadas pela profunda desigualdade entre as partes [ocidental e oriental do país]" (idem). Insistiu na importância de uma rápida, fluida e eficiente reunificação da cidade como modelo e exemplo para o país. E acrescentou que Berlim teria as melhores condições para corporificar o renascimento de uma Alemanha soberana e democrática - com alta e crescente projeção internacional, localizada no coração da Europa (ARNOLD, 1991).

Observe-se que em encontro particular com o então recém-chegado Cônsul-Geral do Brasil em Berlim, Embaixador Álvaro Gurgel de Alencar, o Prefeito Momper abordou esses e outros assuntos de interesse comum. Ele confirmou seu esforço em garantir a transferência efetiva - e não meramente simbólica - das principais agências e ministérios para Berlim, processo gradual que demoraria vários meses ${ }^{24}$. Igualmente, destacou todos os atributos da cidade para realizar plenamente suas tarefas como capital do país. Contudo, reconheceu alguns obstáculos: 1) o alto custo da transferência para o governo federal, 2) a deficiente infra-estrutura, especialmente do lado oriental da cidade, 3) barreiras atitudinais de parcelas significativas da população da ex-RDA em relação aos benefícios, peculiaridades e outras características das economias de livre mercado e 4) a

\footnotetext{
24 Observe-se que parte da burocracia federal, e especificamente o Ministério da Defesa, ficariam em Bonn. Tal determinação demonstrava o interesse de manter vínculos consistentes com a aliança militar ocidental (HAMILTON, 1992).
} 
falta de investimentos dos grandes conglomerados alemães e estrangeiros. Finalmente, o prefeito Momper indicou sua disposição para ajudar os governos que tivessem dificuldades para encontrar instalações para suas embaixadas, inclusive em condições acessíveis (ARQUIVO HISTÓRICO DO MINISTÉRIO DAS RELAÇÕES EXTERIORES, 1990e $)^{25}$.

O status de Berlim como capital da Alemanha terminou sendo assegurado no Segundo Tratado de Unificação, assinado em agosto de 1990 - ainda que acertos posteriores devessem ser pactuados para lograr concluir o processo de transferência até o ano de 1995. Cabe acrescentar que logo após a unificação do país, tanto a cidade de Berlim, como a região da ex-RDA, experimentaram importantes - e às vezes dolorosos - ajustes estruturais com vistas a constituir uma economia de mercado (ARQUIVO HISTÓRICO DO MINISTÉRIO DAS RELAÇÕES EXTERIORES, 1991)26. Os significativos investimentos públicos e privados permitiram uma retomada do crescimento econômico após 1993. Contudo, e curio-

25 Aparentemente o diplomata brasileiro chegou a Berlim
com instruções de fusionar as atividades administrativas
da antiga Embaixada na RDA e do Consultado em Berlim
Ocidental, procurando racionalizar a gestão dos recursos e
eliminar duplicações. Cumpre acrescentar que o violento
aumento de preço dos aluguéis na cidade de Berlim, após a
reunificação do país, atingiu todas as representações diplo-
máticas, e também no caso dos funcionários da representa-
ção brasileira. Em novembro de 1990, Alencar informou
que "vários desses funcionários [da repartição brasileira]
simplesmente não podem mais, com os salários que rece-
bem, entregar ao Consulado-Geral - locatário formal dos
imóveis em que vivem - os recursos para pagamento dos
alugueis". Em conseqüência, resolveu-se transferir a ques-
tão para a Embaixada brasileira em Bonn tomar as provi-
dências cabíveis perante as autoridades germânicas (AR-
QUIVO HISTÓRICO DO MINISTÉRIO DAS RELA-
ÇÕES EXTERIORES, 1990f).

26 O documento em apreço pondera sobre os seguintes tópicos: 1) a grave contração das atividades econômicas no período 1991-1992, geradas pela transição a uma economia social de mercado; 2) a questão do desemprego, subemprego e inflação; 3) comenta decisões judiciais com relação à propriedade de antigos imóveis confiscados e nacionalizados e ao futuro dos servidores públicos da antiga RDA, oferecendo compensações financeiras para os primeiros e limitando a assimilação automática para os segundos; 4) questionamento da oposição e dos sindicatos diante do fechamento de empresas públicas e da perda de vagas de trabalho e 5) perspectivas econômicas futuras da região leste da Alemanha. Conferir Hamilton (1992). samente, de forma reiterada os observadores estrangeiros constataram que, vários anos após a queda do muro, o relacionamento entre os habitantes dos antigos setores leste e oeste da cidade de Berlim continua sendo pouco fluido. Surpreendentemente pesquisas de opinião realizadas desde a época da reunificação da cidade sugerem que ainda existiria um invisível ou virtual muro psicológico entre significativas parcelas da comunidade - hipótese que se demonstraria, por exemplo, com a baixíssima taxa de casamentos entre moradores dos dois setores da metrópole, popularmente conhecidos como ossies e wessies (THE NEWCOMERS LACK SELF-CONFIDENCE, 1990; 'CORTINA DE FERRO’ PERSISTE, 2004).

\section{PÓS-DATA DE NOVEMBRO DE 2009}

Em 9 de novembro de 2009 foi comemorado o vigésimo aniversário da queda do muro de Berlim. Na oportunidade houve encontros de lideranças políticas, festejos populares e apresentações artísticas. A atual Chanceler Angela Merkelrecentemente reeleita no cargo e que no passado morou na RDA -, Helmut Kohl, Mikhail Gorbachev, George Bush (pai) e outros atores privilegiados no processo de tomada que resultou na queda do muro e na reunificação alemã participaram e festejaram o aniversário. Egon Krenz, quebrando um mutismo de vários anos, afirmou que a abertura das fronteiras evitou uma guerra civil e, mesmo reconhecendo a relevância da reunificação da nação, criticou a forma e o ritmo em que foi feita. Com ironia, constatou que "muitos alemães do Leste se sentem como cidadãos de segunda ou de terceira. Em lugar daquele 'nós somos o povo' de 1989, muitos sentem hoje que 'nós éramos o povo"' (KRENZ, 2009). Cumpre destacar que a opinião de Krenz é compartilhada por muitos habitantes do leste da Alemanha. Observe-se, por exemplo, que nas últimas eleições federais, em 27 de setembro de 2009, os neocomunistas, agrupados na chamada coalizão "A Esquerda", triunfaram em vários Estados da antiga RDA e atualmente são a terceira força política mais importante do país, com quase $12 \%$ da simpatia do eleitorado.

Paralelamente, sob a perspectiva da política, da economia e da segurança internacional é evidente que a queda do muro de Berlim acabou sendo um dos mais importantes acontecimentos do século XX. Trata-se de virtual divisor de águas na história mundial, e referência em quase todos 
os campos das Ciências Sociais - inclusive pelas suas implicações no que diz respeito ao fim da Guerra Fria e eventos subseqüentes. Em tal sentido, vinte anos após a queda do muro e da abertura das fronteiras inter-alemãs, muitas das previsões dos diplomatas lotados em Berlim no inicio da década de 1990, particularmente no caso das ponderações supracitadas do Embaixador Ernesto Ferreira de Carvalho, acabaram sendo convalidadas pelo desenvolvimento político, econômico e estratégico da Alemanha reunificada, considerada uma das principais potências nos primeiros anos do século XXI.

Carlos Federico Domínguez Avila (cdominguez_unieuro@yahoo.com.br) é Doutor em História pela Universidade de Brasília (UnB) e Professor do Centro Universitário Unieuro (Unieuro).

\section{REFERÊNCIAS BIBLIOGRÁFICAS}

ADOMEIT, H. 1990. Gorbachev and German Unification: Revision of Thinking, Realignment of Power. Problems of Communism, Washington, D.C., v. 39 , n. 4 , p. 1-23.

ALTMANN, S. 1989. Five Days in October (October 7, 1989). Disponível em: http:// germanhistorydocs.ghi-dc.org/. Acesso em: 15.set.2009.

ARNOLD, E. 1991. German Foreign Policy and Unification. International Affairs, Oxford, v. 67, n. 3 , p. $453-471$.

GADDIS, J. 2005. The Cold War: A New History. Nova York: Penguin.

HAMILTON, D. 1992. Germany After Unification. Problems of Communism, Washington D.C., v. 41, n. 3 , p. 1-18.

HALLIDAY, F. 1990. The Ends of Cold War. New Left Review, London, n. 180, 1990, p. 5-23.

HERTLE, H. 2001. The Fall of the Wall: The Unintended Self-Dissolution of East Germany's Ruling Regime. Cold War International History Project Bulletin, Washington, D.C., n. 12-13, p. 131-164.

KOHL, H. 1989a. Ten Point Program for Overcoming the Division of Germany and Europe, Bonn, 28.11.1989. Disponível em: http://germanhistorydocs.ghi-dc.org/. Acesso em: 15.set.2009.

1989b. Helmut Kohl's Welcome in Dresden (December 19, 1989). Disponível em: http:// germanhistorydocs.ghi-dc.org/. Acesso em: 15.set.2009.
KRAMER, M. 1999. Ideology and the Cold War. Review of International Studies, Cambridge, v. 25 , n. 4 , p. $539-576$.

KRAUSHAAR, E. \& RIEDLE, G. 1990. 'We Want In!'. The Bear is Dancing on the Border. Die Tageszeitung, Berlim Oeste, 11.nov. Disponível em: http://germanhistorydocs.ghidc.org/ . Acesso em: 15.set.2009.

KRENZ, E. 1989. The Well-Being of the People is our Basic Guiding Principle. Declaration of the Chairman of the Council of State of the GDR before the Volkskammer of the GDR on October 24, 1989. Disponível em: http:// germanhistorydocs.ghi-dc.org/. Acesso em: 15.set.2009.

2009. Evitamos una guerra civil. El País, Madrid, 8.nov. Disponível em: http:// www.elpais.com/articulo/reportajes/Evitamos/ g u e r r / c i vil / e l pepus oc d m g/ 20091108elpdmgrep_6/Tes. Acesso em: 9.nov.2009.

MCADAMS, A. 1988. The New Logic in SovietGDR Relations. Problems of Communism, Washington, v. 37, n. 5, p. 47-60.

MODROW, H. 1989. Hans Modrow's Government Program, Berlim, 17.11.1989. Disponível em: http://germanhistorydocs.ghi-dc.org/. Acesso em: 15.set.2009.

MONIZ BANDEIRA, L. 2001. A reunificação da Alemanha: do ideal socialista ao socialismo Real. São Paulo: Global.

RUTLAND, P. 1999. The Revolutions of 1989 Reconsidered. Current History, Philadelphia, p. 147-152, Apr. 
STOKES, G. 1991. Lessons of the East European Revolutions of 1989. Problems of Communism, Washington, v. 40, n. 5, p. 17-22.
WALKER, D. 1992. Germany: Confronting the Aftermath of Reunification. Current History, Philadelphia, p. 359-363, Nov.

\section{OUTRAS FONTES}

ARQUIVO HISTÓRICO DO MINISTÉRIO DAS RELAÇÕES EXTERIORES. 1988. Ernesto Ferreira de Carvalho ao Ministério das Relações Exteriores. Ofício n. 48, Berlim Leste, 18.mai.

1989a. Ernesto Ferreira de Carvalho ao Ministério das Relações Exteriores, Ofício n. 74, Berlim Leste, 26.jul.

1989b. Ernesto Ferreira de Carvalho ao Ministério das Relações Exteriores. Ofício n. 18, Berlim Leste, 15.fev.

1989c. Ernesto Ferreira de Carvalho ao Ministério das Relações Exteriores. Telegrama 170 (confidencial), Berlim Leste, 14.set.

1989d. Ernesto Ferreira de Carvalho ao Ministério das Relações Exteriores. Telegrama 165 (confidencial), Berlim Leste, 12.set.

1989e. Ernesto Ferreira de Carvalho ao Ministério das Relações Exteriores. Telegrama 196 (confidencial), Berlim Leste, 6.out.

. 1989f. Ernesto Ferreira de Carvalho ao Ministério das Relações Exteriores. Telegrama 196 (confidencial), Berlim Leste, 6.out.

.1989g. Ernesto Ferreira de Carvalho ao Ministério das Relações Exteriores. Telegrama 205 (confidencial-urgentíssimo), Berlim Leste, 18.out.

. 1989h. Ernesto Ferreira de Carvalho ao Ministério das Relações Exteriores. Telegrama 216 (confidencial), Berlim Leste, 28.out.

1989i. Ernesto Ferreira de Carvalho ao Ministério das Relações Exteriores. Telegrama 229 (confidencial), Berlim Leste, 9.nov.

1989j. Ernesto Ferreira de Carvalho ao Ministério das Relações Exteriores. Telegrama 249 (confidencial), Berlim Leste, 21.nov.

19891. Ernesto Ferreira de Carvalho ao Ministério das Relações Exteriores. Telegrama 248 (confidencial), Berlim Leste, 21.nov. .1989m. Ernesto Ferreira de Carvalho ao Ministério das Relações Exteriores. Telegrama 234 (confidencial), Berlim Leste, 13.nov.

. 1989n. Ernesto Ferreira de Carvalho ao Ministério das Relações Exteriores. Telegrama 257 (confidencial), Berlim Leste, 29.nov.

. 1990a. Ernesto Ferreira de Carvalho ao Ministério das Relações Exteriores. Ofício 86, Berlim Leste, 23.jul.

. 1990b. Marcel Biato ao Ministério das Relações Exteriores. Telegrama 91 (confidencial), Berlim, 29.jun.

1990c. Marcel Biato ao Ministério das Relações Exteriores. Telegrama 96 (confidencial), Berlim, 10.jul.

. 1990d. Marcel Biato ao Ministério das Relações Exteriores. Telegrama 112 (confidencial), Berlim, 17.set.

.1990e. Álvaro Gurgel de Alencar ao Ministério das Relações Exteriores. Telegrama 145 (confidencial), Berlim, 15.nov.

. 1990f. Álvaro Gurgel de Alencar ao Ministério das Relações Exteriores. Telegrama 155 (confidencial-urgente), Berlim, 27.nov.

. 1991. Álvaro Gurgel de Alencar ao Ministério das Relações Exteriores. Ofício 86, Berlim, 29.mai.

“CORTINA DE FERRO” PERSISTE QUANDO O ASSUNTO É ROMANCE. 2004. Terra, São Paulo, 9.nov. Disponível em: http:// noticias.terra.com.br/mundo/interna/ 0,,OI418901-EI294,00.html. Acesso em: 15.set.2009.

ERICH HONECKER ON THE 40 ${ }^{\mathrm{TH}}$ ANNIVERSARY OF THE GDR (OCTOBER 6, 1989). 1994. In: JARAUSCH, K. \& GRANSOW, V. (eds.). Uniting Germany: Documents and Debates, 1944-1993. Oxford: Berghahn. Disponível em: http:// germanhistorydocs.ghi-dc.org/. Acesso em: 15.set.2009. 
FOUNDING APPEAL OF THE NEW FORUM (SEPTEMBER 9, 1989). 1994. In: JARAUSCH, K. \& GRANSOW, V. (eds.). Uniting Germany: Documents and Debates, 1944-1993. Oxford: Berghahn. Disponível em: http://germanhistorydocs.ghi-dc.org/. Acesso em: 15.set.2009.

GERMAN HISTORICAL INSTITUTE, 2009. German History in Documents and Images (GHDI). Disponível em: http:// germanhistorydocs.ghi-dc.org/index.cfm. Acesso em: 15.set.2009.
SOVIET PROTOCOL OF A CONVERSATION BETWEEN MIKHAIL GORBACHEV AND HANS-DIETRICH GENSCHER (DECEMBER 5, 1989). 2002. In: PLATO, A. Die Vereinigung Deutschlands: Ein weltpolitisches Machtspiel. Berlin: $s / n$. Disponível em: http:// germanhistorydocs.ghi-dc.org/. Acesso em: 15.set.2009.

THE NEWCOMERS LACK SELF-CONFIDENCE. 1990. Der Spiegel, Hamburgo, 12.nov. Disponível em: http://germanhistorydocs.ghidc.org/. Acesso em: 15.set.2009. 


\section{THE FALL OF THE BERLIN WALL: A STUDY BASED ON BRAZILIAN SOURCES}

\section{Carlos Federico Domínguez Avila}

This article explores both the events that led to the fall of the Berlin wall and some of its most important consequences, including those pertaining to German reunification in 1990. We rely largely on primary sources that have been obtained from the Ministry of Foreign Relations' Historical 
Archives - after several years of legal protection. Secondary sources are also used - that is, specialized literature on this theme published in Brazil and abroad. Analytically speaking, we verify the transcendental relevance of the fall of the Berlin wall and subsequent events, both within Germany and in Europe and the rest of the world. In this direction, we allude to the political and economic collapse of the German Democratic Republic (GDR), to the most important actors involved in the crumbling of the wall, to domestic, Inter-German, European and global factors that were incisive in the processes of reunification of the German nation and to the specific dilemmas of the city of Berlin within the general context of Germanic reunification. We include a post-data from November of 2009, with some brief comments on the 20th anniversary commemoration of the fall of the Berlin Wall.

KEYWORDS: Democratic Republic of Germany; Berlin; Cold War; German reunification; Federal German Republic. 
LA CHUTE DU MUR DE BERLIN : UNE ETUDE AVEC DES SOURCES BRESILIENNES

Carlos Federico Domínguez Avila

L'article explore les événements qui ont résulté à la chute du mur de Berlin, bien comme quelques unes de ses plus importantes conséquences, y compris par rapport à la réunification allemande, en 
1990. Le texte utilise prioritairement, des sources primaires récupérées dans l'Archive Historique du Ministère des Relations Extérieures du Brésil - après plusieurs années de précaution légale. Des sources secondaires sont aussi utilisées - c'est-à-dire, de la littérature spécialisée dans le thème, publiée au Brésil et à l'étranger. Analytiquement, l'article constate la transcendantale importance de la chute du mur de Berlin et les événements subséquents, en Allemagne elle-même, en Europe et dans le monde. En suivant cette ligne de raisonnement, le texte fait référence au collapse politique et aussi économique de la République Démocratique de l'Allemagne (RDA); aux acteurs fondamentaux qui ont mené à l'effondrement du mur ; aux contraintes nationales, interallemandes, européennes et mondiales, qui ont abouti au processus de réunification de la nation allemande et aux dilemmes spécifiques de la ville de Berlin dans le contexte général de la réunification germanique. Le travail inclut une postdate de novembre 2009, où les commémorations du vingtième anniversaire de la chute du mur de Berlin, sont brièvement commentées.

MOTS-CLES : République Démocratique de l'Allemagne ; Berlin ; Guerre Froide ; réunification allemande ; République Fédérale de l'Allemagne. 